\title{
The Question of Original Sin in Hamlet
}

\author{
John Gillies
}

$\mathrm{T}$ He idea that original Sin IS NOT ONLY PRESEnT In Hamlet but also heavy with moral and aesthetic meaning is relatively recent but also implicit at earlier stages of the critical tradition. In 1980, Alan Sinfield crucially drew attention to Hamlet's "special providence in the fall of a sparrow" (F 5.2.167-68) as the play's Calvinist turning point, one which "we are slow to recognise because we have been taught a more amiable conception of the Christian God." Some few years later, Philip Edwards asserted the play's "religious element" after the moral disenchantment of the "anti-Hamlet" school of the midcentury. ${ }^{2}$ Although the anti-Hamlet critics had not grasped the pertinence of original sin to their own argument, in retrospect, their leveling of the moral distinctions between Hamlet and his adversaries is clearly in step with more recent original-sin readings, not to mention a longstanding "counter-enlightenment" project to rehabilitate original sin as a philosophical category. ${ }^{3}$ What Edwards and Sinfield reluctantly

I thank Ewan Fernie and Peter Holbrook, fellow panelists at our 2012 Shakespeare Association of America panel on Shakespeare and original sin, Richard Strier for an important reference in Calvin, John Drakakis for a lucid discussion of Hamlet's last moments, Marion O'Connor for tips on early Tudor Protestant drama, and Dan Watts for hosting the ongoing Kierkegaard seminar at Essex. I also thank the two readers for Shakespeare Quarterly.

${ }^{1}$ Alan Sinfield, "Hamlet's Special Providence," Shakespeare Survey 33 (1980): 89-98, esp. 93. Citations of Q1 and F follow Hamlet: The Texts of 1603 and 1623, ed. Ann Thompson and Neil Taylor (London: Arden Shakespeare, 2006). Thompson and Taylor's edition of Q1 is cited within the text by scene and line number; their edition of $\mathrm{F}$ is cited by act, scene, and line. Quotations of Q2 follow Hamlet, ed. Ann Thompson and Neil Taylor (London: Arden Shakespeare, 2006) and are quoted in the text by act, scene, and line. Quotations of Shakespeare's plays other than Hamlet are taken from The Oxford Shakespeare: Complete Works, ed. Stanley Wells and Gary Taylor (Oxford: Clarendon Press, 1998) and are cited by act, scene, and line.

2 "I personally cannot see a way forwards in any discussion of Hamlet, that does not take as a point of departure that it is a religious play"; see Philip Edwards, "Tragic Balance in Hamlet," Shakespeare Survey 36 (1983): 43-52, esp. 45.

${ }^{3}$ See especially Joseph de Maistre, The St. Petersburg Dialogues, ed. Richard E. Lebrun (Montreal: McGill-Queen's UP, 1983). Disciples tend to be of the right like E. M. Cioran and Charles Baudelaire, but De Maistre's influence can be traced in writers of the left such as Adorno: "Too little that is good has power in the world for the world to be said to have achieved progress, but there can be no good, not even a trace of it, without progress." See Theodor W. Adorno, History and Freedom: Lectures 1964-1965, ed. Rolf Tiedemann (Cambridge: Polity Press, 2010), 149. Adorno comments favorably on De Maistre (24). 
acknowledged is the virtually scandalous thought welcomed by Kierkegaard: that the conclusion of Hamlet is deliberately framed in religious categories and is incomprehensible without them. Kierkegaard imagines Hamlet shrinking back from his revenge in "religious doubt" or a religious horror at the depravity of human nature. ${ }^{4}$ By contrast, Sinfield's Hamlet, like those Dutch and Huguenot Protestants who evolved a theory of resistance or "controlled revolt" from Calvin, "believes that providence wants Claudius removed and that he should do it." Edwards, remarking the disinclination of the anti-Hamlet critics to endorse Hamlet's sense of holy mission, concludes, "It is not faith we need to understand Hamlet but doubt about our own skepticism." ${ }^{6}$ We might say that independently of its becoming an object of critical discussion, the meaning of original sin in Hamlet has been in question.

The theme of original sin was explicitly recognized in Donald V. Stump's demonstration of how motifs of the Fall and Cain's murder of Abel in chapters 3 and 4 of Genesis join in a coherent thematic symbolism. ${ }^{7}$ The result is a leveling reading: Hamlet's disastrous impatience with Providence shows that he "is doomed to become like Cain." 8 Catherine Belsey teases out further links between the Fall story and that of Cain in the context of Elizabethan family values. ${ }^{9}$ Heather Hirschfeld reads the architecture of the Fall in terms of the logic of trauma: "It is this type of deferred or belated recognition that underwrites the sustained allusions throughout Hamlet to the early chapters of Genesis." 10 The play presents us with "a narrative of repeated and deferred recognitions," the effect of which is to capture Hamlet's project within a compulsive rehearsal of sin's traumatic origin. This logic extends to the supposed metanoia of Act 5, which is no "providential sea change." Hirschfeld's is the most comprehensive original-sin reading of Hamlet that we have and, to my mind, the most thoughtful. Insofar as it sees Hamlet's awareness of original sin condemning him to repetition, it too is a leveling reading. Two further leveling studies are

4 "If Shakespeare does not give Hamlet religious presuppositions that conspire against him in religious doubt ... then Hamlet is essentially a vacillator"; see Søren Kierkegaard, "A Side Glance at Shakespeare's Hamlet," in Stages on Life's Way, ed. Howard V. Hong and Edna H. Hong (Princeton: Princeton UP, 1998), 452-54, esp. 453.

${ }^{5}$ Sinfield, 94-95.

${ }^{6}$ Edwards, "Tragic Balance in Hamlet," 52.

${ }^{7}$ Donald V. Stump, "Hamlet, Cain and Abel, and the Pattern of Divine Providence," Renaissance Papers (1985): 27-38.

${ }^{8}$ Stump, 35

${ }^{9}$ Catherine Belsey, Shakespeare and the Loss of Eden: The Construction of Family Values in Early Modern Family Culture (Houndsmills, UK: Macmillan, 1999), 129-74.

${ }^{10}$ Heather Hirschfeld, "Hamlet's 'first Corse': Repetition, Trauma, and the Displacement of Redemptive Typology," Shakespeare Quarterly 54 (2003): 424-48, esp. 426.

${ }^{11}$ Hirschfeld, 426, 442. 
worthy of mention. John Alvis comes at the play from the republican angle of Machiavelli's commentary on Livy, wanting to know why Hamlet can't dispose of the tyrant cleanly. To Alvis's chagrin, the answer is that Hamlet is disabled by his original-sin fixation. ${ }^{12}$ Finally, Vladimir Brljak reads Hamlet's excuse to Laertes in Act 5 for killing Polonius ("That I have shot mine arrow o'er the house / And hurt my brother" [Q2 5.2.190-91]) as a reference to a late medieval legend derived from an obscure utterance in Genesis 4 by Lamech (an impious descendant of Cain whose inadvertent killing of Cain brings God's curse upon him) ${ }^{13}$ Again, the consequence for Hamlet-whose traditional name "Amleth" is an anagram of "Lameth," a common form of "Lamech"—is a leveling of moral distinction. Of all these original-sin-focused studies, only Belsey's is not a leveling reading.

To my mind, the presence of original sin in the play provokes more fundamental questions than have been asked so far. Why, given the associated problem of "tragic balance", is it present at all? Where does the theme come from? Is original sin a mental illness or an ideology? Must it be understood primarily in a mythic-symbolic register or a doctrinal one? One of my suggestions will be that while the narrative in Genesis is a given, its interpretation is not, and particularly not during the Reformation. This prompts another question about the play: to what extent is this doctrinal element of the radically reformed kind? And if it is, then what are its aesthetic consequences? Does original sin mandate a leveling reading? In what follows, I address these questions via four related propositions.

First, I point to the intuitiveness of original sin in the sense of radical doubt of human goodness as distinct from a doctrine in its early modern context. The idea has classical, as well as scriptural, contexts. However deranging it might be for the holder, such radical doubt is neither irrational nor even necessarily religious. That is, it has a conceptual shape, religious and philosophical forms of which are present in two Shakespeare plays closely contemporary with Hamlet.

Second, I insist on the sheer deliberateness of the theme, which is no part of the plot's surviving sources (Saxo Grammaticus and Belleforest) but is introduced entirely at Shakespeare's discretion. ${ }^{14}$ This might seem a superfluous claim to make, but my point is to demonstrate full Shakespearean ownership. Existing criticism has a tendency to treat original sin as an emblematic monad that somehow takes over the meaning of the play. This said, however, the theme

12 John Alvis, "Shakespeare's Hamlet and Machiavelli: How Not to Kill a Despot," in Shakespeare as Political Thinker, ed. John E. Alvis and Thomas G. West (Wilmington, DE: ISI Books, 2000), 289-313.

13 Vladimir Brljak, "Hamlet and Lameth," Notes and Queries 58 (2011): 247-54.

${ }^{14}$ I make no assumptions about the lost Ur-Hamlet of ca. 1589. 
does betray an extra-Shakespearean origin comprising not just the narrative of Genesis 3 and 4 but the Reformed theological commentary upon that narrative.

Third, I argue that the theme is fully absorbed into the aesthetic DNA of imagery, language, and character. The whole personal and interpersonal world said to be under sin in the play is imagined with a depth and mystery without precedent in Shakespeare. It is not just the character of Hamlet that is affected, but Claudius, Gertrude, and the whole society that Michael Long refers to as "Elsinore,"15 right down to the seedy occupants of Hamlet's graveyard, those word-twisting avatars of "Cain's jawbone" (F 5.1.77). Here, I contend that the distinctiveness of the language in Hamlet owes quite as much to the original-sin theme as it does to revenge.

Fourth, I turn to Hamlet's persistent intuition of original sin and his struggle with the politics of conscience. ${ }^{16}$ Given that Hamlet is hobbled by religious doubt, in Kierkegaard's sense, can he kill Claudius without corrupting himself? Hamlet's attempt to conscript conscience to revenge is certainly ambiguous and possibly futile, leading to a conclusion heavy with religious doubt, but touched equally by the promise of salvation.

It is important to register the intellectual intuitiveness of original sin in late Elizabethan England. That the timber of humanity is crooked - the heart desperately wicked-is never in need of demonstration. Luther observes that scripture "calls this viciousness by the name most proper to it . . . iniquity, depravity or crookedness." 17 For Calvin, it is obvious that "there is no sounde or whole parte in us ... that our minde is stricken with blindnesse ... that all the affections of our heart are full of rebellion and wickedness"; "man's heart is . . inclosed with ... lurking corners and by-turninges." ${ }^{18}$ When the religious tone is subtracted, moral doubt remains. Virtue is not the full story of success: one flourishes because of one's cunning, not despite it or because of the ability to disguise one's own intentions while second-guessing those of others. Bacon warns against suspicion not because it is unwarranted ("What would men have? Do they think those they employ and deal with are saints? Do they not think, they will have their own ends, and be truer to themselves, than to them?") but

${ }^{15}$ Michael Long, The Unnatural Scene: A Study in Shakespearean Tragedy (London: Methuen, 1976), 127-29.

${ }^{16}$ For a discussion of the link between the doctrine of original sin and conscience in the sense of compliance, see my "Calvinism as Tragedy in the English Revenge Play," Shakespeare (published online 22 October 2013), DOI: 10.1080/17450918.2013.845598, 1-26, esp. 1-6.

${ }^{17}$ Martin Luther, Lectures on Romans, ed. Hilton S. Oswald, in Luther's Works, 55 vols. (St. Louis, MO: Concordia Publishing House, 1955-76), 25:292.

${ }_{18}$ A Commentarie of John Calvine, upon the first booke of Moses called Genesis (London, 1578), 94-95. 
because it is more likely to derange us than serve our interest ("Therefore there is no better way, to moderate suspicions, than to account upon such suspicions as true, and yet to bridle them as false"). ${ }^{19}$ One reason for the intuitiveness of original sin in the early modern period is that self-interest had yet to be categorized - as it would be by Shaftesbury in 1699-as a naturally occurring human endowment, an ontological predisposition without moral meaning as such. ${ }^{20}$

This bicameral view of self-knowledge implicit in Of Suspicion was explicitly held by the Reformers. For Calvin, a man "seems to know himself very well when, confident in his understanding and uprightness, he becomes bold and urges himself to the duties of virtue, and, declaring war on vices, endeavors to exert himself with all his ardor towards the excellent and the honorable."21 From this piano nobile level of the self, good deeds proceed, which is why the Reformers held them to be spiritually insignificant. At a lower level, that of "the ground of the heart," a man "finds nothing to lift his heart to self-confidence."22 He finds instead "Hydra, a many-headed and most tenacious monster, with which we struggle in the Lernean swamp of this life till the very day of our death."23

The bicameral model of the self is not exclusive to the Reformers. In a passage of the Phaedrus that is cited by both Joseph de Maistre and Søren Kierkegaard as evidence that the ancients knew about original sin, Socrates entertains a philosophical version of religious doubt: "I can't as yet 'know myself' ... [or] discover whether I really am a more complex creature and more puffed up with pride than Typhon, or a simpler, gentler being whom heaven has blessed with a quiet, un-Typhonic nature." 24

${ }^{19}$ Francis Bacon, "Of Suspicion," in Essays, ed. Michael J. Hawkins (London: Dent, 1972), $100-101$.

20 "We know that every creature has a private good and interest of its own, which nature has compelled him to seek by all the advantages afforded him within the compass of his make." See Anthony Ashley Cooper, Third Earl of Shaftesbury, "An Inquiry Concerning Virtue or Merit," in Characteristicks of Men, Manners, Opinions, Times, ed. Philip Ayres, 2 vols. (Oxford: Clarendon Press, 1999), 1:163-230, esp. 167.

${ }^{21}$ John Calvin, Institutes, 2.1.3, in Calvin: Institutes of the Christian Religion, ed. John T. McNeill, 2 vols. (Louisville, KY: Westminster John Knox Press, 1960), 1:243-44.

22 Tyndale's New Testament, Translated from the Greek by William Tyndale in 1534, ed. David Daniell (New Haven: Yale UP, 1989), 207; and Calvin, Institutes, 2.1.3.

${ }^{23}$ Luther, Lectures on Romans, 25:300.

${ }^{24}$ Plato, Phaedrus, in The Collected Dialogues of Plato, ed. Edith Hamilton and Huntington Cairns (New York: Pantheon Books, 1961), 475-525, esp. 478 (section 230a). Joseph de Maistre observes of this passage that "original sin could not be more clearly admitted" (199). The passage is independently cited in Kierkegaard: "Socrates, despite being very knowledgeable about human nature and having a great deal of self knowledge, did not know with certainty whether he was'a more complex creature and more puffed up with pride than Typhon, or a simpler, gentler being." See Søren Kierkegaard, Repetition and Pbilosophical Crumbs, ed. Edward F. Mooney and M. G. Piety (Oxford: Oxford UP, 2009), 31. 
Like Hydra, Typhon is a serpentine monster. Such symbolism is recapitulated in Reformed art in figures such as Spenser's "Error," the many-headed beast bestridden by the Whore of Babylon in Revelation, or the "Hydra-headed wilfulness" of Henry $V(1.1 .36)$. A version of serpentine dualism is also behind Plato's antiparable of Gyges in book 2 of The Republic ${ }^{25}$ In contrast to the final paean to justice in book 1 , book 2 begins with a scandalously minimalistic account. As Glaucon argues, "Justice, they tell us . . . is accepted and approved, not as a real good, but as a thing honored in the lack of vigor to do injustice." ${ }^{26}$ Justice exists only because human beings are less confident of prevailing unjustly than they are afraid of the injustice of others. Fear aside, injustice is the default setting of the human psyche even in the just man: "If we grant to both the just and the unjust license and power to do whatever they please, and then accompany them in imagination. ... We should then catch the just man in the very act of resorting to the same conduct as the unjust man because of the self-advantage which every creature by its nature pursues as a good." 27 The parable of Gyges and the magic ring follows. Upon discovering a ring that makes him invisible, Gyges, a humble Lydian shepherd, infiltrated the king's palace, "seduced the king's wife and with her aid set upon the king and slew him and possessed his kingdom." 28 Whether he was directly or indirectly ${ }^{29}$ familiar with this parable, Shakespeare descants on its inherent moral skepticism. Thus, hearing that his father has been declared a "traitor," young Macduff inquires into the definition of a traitor and decides that society is packed with them (Macbeth, 4.2.45-60). The parable is equally suggestive of Hamlet, both for Claudius (a previously inconspicuous man whose road to success closely resembles that of Gyges) and for Hamlet himself, the just man who restrains his inner violence only because of a watchful conscience that "does make cowards of us all" (F 3.1.83).

Profound moral doubt seems to me the doorway through which the idea of original sin enters Hamlet. Seeing himself in the mirror of Gertrude whose marriage to Claudius shocks him with its hint of inner monstrosity, Q2's Hamlet is stricken by disgust at his own "sallied" flesh (Q2 1.2.129). Similar

${ }^{25}$ For a discussion of the Gyges story in the context of original sin to which I am indebted, see Patrick Downey, Desperately Wicked: Philosophy, Christianity and the Human Heart (Downers Grove, IL: Intervarsity Press, 2009), 15-29.

${ }^{26}$ Plato, The Republic, in Dialogues, 575-844, esp. 607 (sections 359a-b).

${ }^{27}$ Plato, Republic, in Dialogues, 607 (section 359c).

${ }^{28}$ Plato, Republic, in Dialogues, 607 (sections 359-60b).

${ }^{29}$ Cicero rehearses the Gyges story but draws the opposite moral: "If a wise man ... were to have the same ring, he would think himself no more free to do no wrong than if he did not have it." See On Duties, ed. M. T. Griffin and E. M. Atkins (Cambridge: Cambridge UP, 1993), 112-15, esp. 114. As Katherine Eisaman Maus has shown, religious polemicists read Cicero's Gyges story with something of Plato's skepticism; see Inwardness and Theater in the English Renaissance (Chicago: U of Chicago P, 1995), 35-47. 
moral pessimism, along with an explicit theme of self-contradiction, is also at the heart of other contemporary plays. Although its idiom is entirely classical, Troilus and Cressida asks a version of the skeptical question posed by original $\sin$. In a scene strongly reminiscent of Hamlet, Ulysses is discovered reading a book on the theme that identity is a mere artifact. Self-knowledge is no more than an accurate sense of what others think of us:

Nor doth the eye itself, That most pure spirit of sense, behold itself, Not going from itself; but eye to eye opposed Salutes each other with each other's form. For speculation turns not to itself Till it hath travelled and is mirrored there Where it may see itself.

(Troilus and Cressida, 3.3.100-106)

While this approach to the question of the bicameral self is from the upper chamber, rather than the Lutheran "ground of the heart," the conclusion is still devastating. Self-knowledge is limited to the little part of us that others behold. The self is fatally beholden to a given peer group or social world. Cressida breaks her deepest vows as soon as she finds herself in a social world with different claims on her. Hector abandons what he rightly takes to be the true course-returning Helen to the Greeks-simply to bask in the approval of his own heroic cult. With the mirrors of esteem clouded, Achilles finds no selfimage at all:"My mind is troubled like a fountain stirred, / And I myself see not the bottom of it" (11. 298-99).

Transposed to the Christian idiom of Measure for Measure, the mirror metaphor of Troilus and its ontological skepticism are restated in a theological key:

But man, proud man,

Dressed in a little brief authority,

Most ignorant of what he's most assured,

His glassy essence, like an angry ape

Plays such fantastic tricks before high heaven

As makes the angels weep, who, with our spleens,

Would all themselves laugh mortal.

(Measure for Measure, 2.2.120-26)

The identity or "essence" of the magistrate, argues Isabella, is "glassy" in two senses: in retorting a vacuous social esteem, and in the intoxicating effects of that esteem. (Here, Angelo is the ape driven mad by its own reflection in a mirror.) In keeping with the Christian character of this play, the mirror metaphor is framed in terms of original sin: we are all wrong in the core of our being, Isabella reminds Angelo (11. 75-81), and earthly judges do well to bear 
that in mind. The ape and its mirror (speculum) are a cosmic spectacle or theater. The ontological skepticism of the theatrum mundi helps explain why it was one of Calvin's favorite commonplaces. ${ }^{30}$

\section{II}

My second proposition concerns the centrality of original sin in Hamlet, its deliberateness, its patently Reformed quality, and its origins in Reformed commentary on Genesis. The symbolism of original sin is global in a still-unacknowledged way. It saturates the motif of hidden corruption so well described by Carolyn Spurgeon:

To Shakespeare's pictorial imagination ... the problem in Hamlet is not predominantly that of will and reason, of a mind too philosophic or a nature temperamentally unfitted; he sees it pictorially not as the problem of an individual at all, but as something greater and even more mysterious, as a condition for which the individual himself is apparently not responsible, any more than the sick man is to blame for the infection which strikes and devours him, but which, nevertheless ... impartially and relentlessly, annihilates him and others innocent and guilty alike. That is the tragedy of Hamlet, as it is perhaps the chief tragic mystery of life. ${ }^{31}$

Examples are the "vicious mole of nature" passage in Q2 (1.4.17-38), ${ }^{32}$ "something ... rotten in the state of Denmark" (F 1.4.65), and what-in F only-Hamlet describes as "this canker of our nature" (F 5.2.69). Spurgeon finds this theme so potent that she suggests, "When the play opens Hamlet has already begun to die, to die internally ... infected by the disease of the spirit which is-unknown to him-killing him." ${ }^{33}$ Her intuition here is close to the idea of modern (as distinct from ancient) tragedy that Kierkegaard entertains in the theorem of a modern Antigone, whose "life is ... essentially over" at the start of her play: "Her life does not unfold like the Greek Antigone; it is not turned outward but inward." 34 Unlike the tragedy of the Greek Antigone, which consists of the acting out of her defiance, that of Kierkegaard's modern Antigone is the reflective "anxiety" that she brings to her play. Kierkegaard's model for the anxious Antigone is patently Hamlet: "Anxiety is essential to the

${ }^{30}$ R. S. White, "Theatrum mundi: The Theatre Metaphor in Calvin," Australian Journal of French Studies 31 (1994): 309-25.

${ }^{31}$ Carolyn Spurgeon, Shakespeare's Imagery and What It Tells Us (1932; repr., Cambridge: Cambridge UP, 1996), 318-19.

${ }^{32}$ Hirschfeld discusses this well, as recapitulating a pattern of traumatic narrative repetition within Genesis (438-39).

${ }^{33}$ Spurgeon, 318.

${ }^{34}$ Søren Kierkegaard, "Ancient Tragedy's Reflection in the Modern," in Either/Or: A Fragment of Life, ed. and trans. Alasdair Hannay (London: Penguin, 1992), 137-61, esp. 154. 
tragic. Hence Hamlet is deeply tragic." ${ }^{35}$ Kierkegaard's anxiety corresponds to Spurgeon's "pictorial imagination" (infection) in Hamlet. Likewise, Schopenhauer provides a conceptual gloss on what Spurgeon sees in pictorial terms, noting that "the true sense of the tragedy is the deeper insight that what the hero atones for is not his own particular sins, but original sin, in other words, the guilt of existence itself." 36

Much as for Kierkegaard, tragedy for Schopenhauer is about original sin. To gloss Spurgeon's reading of Hamlet in this way is not too much of a liberty. The motif of infection recapitulates a Senecan symbolism of tumor that Sidney sees as essential to tragedy as a genre:"Tragedy showeth forth the ulcers that are covered with tissue." ${ }^{37}$ Seneca's image of the tumor and Sidney's image of the ulcer resonate in turn with the Reformed symbolism of original sin. Luther imagines fomes, or "the tinder of concupiscence," as a chronic disease that can be controlled but that "break[s] forth ... even as an evil scab or a pock cannot always be kept in with violence of medicine." 38

While the imagery of original sin is global as I have just discussed it above, that same imagery in Hamlet can strike us as incongruous, as savoring too strongly of Reformed theology. Consider Polonius's instruction to Reynaldo to spread rumors of Laertes's wildness. Reynaldo must not impute positive "dishonor" to Laertes (F 2.1.27), but merely hint at

the taints of liberty,

The flash and outbreak of a fiery mind,

A savageness in unreclaimed blood,

Of general assault.

Reynaldo must suggest "wanton, wild, and usual slips" (F2.1.22) which should not be "so rank / As may dishonour him" (F 2.1.20-21). The words "slips" and "rank" link this imagery with the "unweeded garden / That grows to seed," the postlapsarian garden possessed of "things rank and gross in nature" (F 1.2.133-34). ${ }^{39}$ There is a curiously insistent theological quality to Polonius's words; this savage

${ }^{35}$ Kierkegaard, “Ancient Tragedy's Reflection," 153.

${ }^{36}$ Arthur Schopenhauer, The World as Will and Representation, trans. E. F. J. Payne, 2 vols. (New York: Dover, 1969), 1:254.

${ }^{37}$ Sir Philip Sidney, An Apology for Poetry, ed. Geoffrey Shepherd (Manchester: Manchester UP, 1973), 117.

38 The passage is from Tyndale's translation of Luther's prologue to Paul's Epistle to the Romans (Tyndale's New Testament, 208).

${ }^{39}$ For the definition of "slip" as "twig, sprout or small shoot," see OED Online (Oxford: Oxford UP, December 2013), http://www.oed.com/view/Entry/181876? rskey=v3IVg1\&result=2\& is Advanced=false (accessed January 20, 2014), s.v. "slip, $n^{2}$," 1 . For an explicitly Calvinist version of this imagery, see the cover illustration to this issue and n. 42, below. 
blood is "unreclaimed." As there is no possibility that Laertes is unbaptized, this can only mean that he is not redeemed from sin, that he is not of the elect (unlike, presumably, Polonius himself). Fortinbras is similarly described as someone "Of unimproved mettle, hot and full" (F 1.1.95). "Unimproved," according to G. R. Hibbard, is a Shakespeare coinage meaning "untried." ${ }^{40}$ Yet in conjunction with the associated picture of gross rebellion-Fortinbras "hath in the skirts of Norway, here and there, / Sharked up a list of landless resolutes" (F 1.1.96-97) - the coinage takes on a Reformed tint, of the old Adam rather than the new man.

Such incongruities might remind us that original sin is no part of the traditional Hamlet narrative in either Saxo Grammaticus or Belleforest. Like the episode of Lucius Junius Brutus in Livy that it loosely resembles, the Amleth story is all about decisive action. ${ }^{41}$ There is no hint of Kierkegaard's religious doubt in Amleth or Brutus; Shakespeare introduces it against the grain of the material. In the sources, madness is necessary to protect Amleth from the raw violence of his adversary Fengo. In Shakespeare, a disguise is not strictly necessary because Claudius is not openly violent and poses no immediate danger, hence the very different character of madness in Hamlet as a window into the hero's theological demoralization. The distance between source and play is too manifold to be shown here, but it can be suggested by what Shakespeare makes of a single narrative detail. In the sources, the Ophelia figure is sent by Fengo as bait to entice Amleth's secret, but from either friendship or love she remains loyal. In Shakespeare, Ophelia loves Hamlet but sides with her father's attempt to spy on him.

What Shakespeare principally makes of this narrative cue is the nunnery scene (F 3.1), the clearest instance of the play's original-sin theme and a scene in which the theme's doctrinal focus is distinct from the narrative-symbolic. More than anywhere else in Hamlet, we sense the theme in its strongly Reformed character. Consider a line such as "virtue cannot so inoculate our old stock but we shall relish of it" (F 3.1.117-19). Only in Lutheran and Calvinist doctrine is virtue no part whatever of our natural competence. Moral strength is ours at all only by divine imputation. It is ours in a secondary sense through the Atonement rather than in the primary sense of natural law. Virtue is grafted to our nature, as in the gardening metaphor of the word "inoculate." Yet the "old stock," the warped natural root, persists regardless of how well the grafting takes. ${ }^{42}$

${ }^{40}$ G. R. Hibbard, ed., Hamlet (Oxford: Oxford UP, 1987), 150.

${ }^{41}$ For a discussion of the Brutus story, see Andrew Hadfield, Shakespeare and Republicanism (Cambridge: Cambridge UP, 2005), 184-204.

${ }^{42}$ Webster too registers shock at the thought that virtue might not have a natural component. Compare The Duchess of Malfi, ed. John Russell Brown (Manchester: Manchester UP, 1976): "Virtue, where art thou hid? what hideous thing / Is it that doth eclipse thee? . . / Or is it true, thou art but a bare name, / And no essential thing?" (3.2.71-74). 
Although brilliantly assimilated to the aesthetic structure, the doctrinal element visibly imprints itself upon the scene. The imagery derives from Romans 11:16-20, which explains the grafting of the Gentiles to the elect stock of Abraham. Hamlet's remark echoes both the spirit and letter of Calvin's commentary to this passage - "For the original of the Gentiles was (as it were) of a wilde and barren olive: because they found nothing in their whole petegrie but malediction. Therefore whatsoever glorie they have, that is of the newe grafting and not of the olde stocke." ${ }^{43}$ While for Calvin, the "horror, weariness, anxietie, and desperation" arising from contemplating "the miserable condition of our nature" 44 ("the olde stocke") leads us toward God, for Hamlet it takes us nowhere. Hamlet's tone is hardly pious. The word "relish" seems to twist a Calvinist metaphor of taste. In Thomas Norton's Elizabethan translation of the Institutes, we read that the newly faithful will develop a "taste" for higher things: "And so man's understanding ... doth never till then truely begin to tast of those thinges that belong to the kingdome of God, being before altogether unsavourie and without iudgement of tast to take assay of them. ${ }^{35}$ For Calvin, the taste of the elect is proactive rather than retroactive: it is literally in bad taste for the elect to compulsively savor their root condition (as Hamlet does). The verbal tease continues; Hamlet vows to kill Claudius in an act "that has no relish of salvation in't" (Q2 3.4.92). Here, the verbal echo underlines an uncomfortably Calvinist continuity between hero and villain: the virtuous man who relishes the "old stock" and the reprobate who providentially dies in an act relishing of salvation.

These two dimensions of the original-sin theme-the symbolism derived from the Fall narrative in Genesis 3 and 4, and the doctrine of totalized taint echoed by Hamlet in the nunnery scene-are powerfully fused in Luther's and Calvin's commentaries on Genesis. The Calvinist reading of Genesis was commonplace in late Elizabethan England, and if not directly Shakespeare would have known it from Calvinist marginalia to Genesis and Romans in his copy of the Geneva Bible. He

\footnotetext{
43 A Commentarie upon the Epistle of Saint Paul to the Romanes, trans. Christopher Rosdell (London, 1583), 153. Calvin accommodates this passage to his key concept of personal election, as illustrated by the emblematic frontispiece to In Librvm Psalmorum, Iohannis Caluini Commentarius (Geneva, 1557). The image is reproduced on the cover of this issue. It shows a man standing beneath a tree surrounded by a pile of lopped yet still leafy branches. The branches remaining on the tree are grafted and are fruit-bearing; sap runs from a gash in the trunk. The man speaks the words, "Noli altum sapere," the Vulgate's version of Romans 11:20. See Biblia Sacra Vulgatae Editionis (Rome: Congregationis de Propaganda Fide, 1861) 748. The Geneva Bible renders this as "Bee not high minded but feare"; see The Geneva Bible: The Annotated New Testament, 1602 Edition, ed. Gerald T. Sheppard (New York: Pilgrim Press, 1989), 77.

${ }^{44}$ Calvin, Commentarie upon ... Romanes, 153.

45 The Institution of the Christian Religion written in Latine by M. Iohn Calvine, and translated into English, by Thomas Norton (London, 1578), 3:2, 34, 234.
} 
could also have known of it through Joshua Sylvester's translation of Du Bartas's highly Calvinistic recounting of Genesis 3 and 4 in The Second Weeke or Childhood of the World (1598). ${ }^{46}$ Indeed, I argue that Hamlet bears distinct traces of Du Bartas, as well as an overall imaginative and theological coloration.

Traditional Genesis commentary was largely typological, a strategy driven in part by the church fathers' embarrassment in the face of the glaringly unChristian character of the Old Testament corpus. ${ }^{47}$ But Luther and Calvin, far from being embarrassed by the Old Testament, took it as an invitation to dramatize themes of faith, election, predestination, and reprobation with a vividness lacking in their New Testament commentaries. In its very understatement, the Old Testament offered opportunities for imaginative surmise or proactive reading that the New Testament did not. Undergirding Reformed enthusiasm for the Old Testament was a conviction that it was in essence a Christian document to which the radical propositions of Reformed theology could apply with a freedom and intensity not permitted by the New Testament. Of Luther, Heinrich Bornkamm observes, "The incessant translation of Old Testament ideas into the Christian thought world-as into a foreign language-involves not so much a shift in concepts which can be precisely specified as a change in atmosphere which often can only be sensed. Such translation is not a matter of conscious and intentional change, but rather a natural process of recasting, which involves every part. ... When Luther interpreted and translated the Old Testament he injected the gospel into its bloodstream so that it spread into the smallest capillaries almost by itself." 48

Calvin too saw the two testaments as essentially one, systematically reading the Old through the New: "Thus the two Covenants become one, the two Churches one, the two sets of writings, one book." 49 Where the Old Testament had been read as explicitly opposing the New-a covenant of the law versus a covenant of grace-the Reformers saw the Old Testament as a covenant of grace, with its true exemplars accessing grace by spiritual intuition. Only its false

${ }^{46}$ Genesis 3 is recounted in "Eden: The I Part of the I Day of the II Week," and "The Imposture: The I Part of the I Day of the II Week"; Genesis 4 is recounted in "The HandyCrafts: The IIII Part of the I Day of the II Week." For simplicity's sake, further references to Du Bartas will cite sections by name and line number. For the full text of the 1598 English edition, see The Divine Weeks and Works of Guillaume de Saluste Sieur Du Bartas, Translated by Joshuah Sylvester, ed. Susan Snyder, 2 vols. (Oxford: Clarendon Press, 1979), 1:316-37, 338-56, 380-402.

${ }^{47}$ See T. H. L. Parker, ed., Calvin's Old Testament Commentaries (Edinburgh: Clark, 1986): "The general tendency was to give the Old Testament a lower religious position than the New" (44).

${ }^{48}$ Heinrich Bornkamm, Luther and the Old Testament, ed. Victor I. Gruhn, trans. Eric W. Gritsch and Ruth C. Gritsch (Philadelphia: Fortress Press, 1969), 219-20.

${ }^{49}$ Parker, ed., 47-48. 
exemplars epitomized the law. The Reformers detected a prototype of the Reformed church as far back as the primitive congregation of Adam, Eve, and Seth. The majority church of the Old Testament was a church of the law, which means a church of pharisaical legal observance.

Both Reformers bring this new immediacy to their readings of Genesis 3 and 4. It is no exaggeration to say that they treat the main figures of Adam, Eve, and Cain in the way that Jan Kott treats Shakespeare's characters, as "contemporaries," which is to say, as exemplars of Reformed theological psychology. ${ }^{50}$ Two key notions bridge the gap between the "there-ness" of Genesis and the "here-ness" of early modernity: faith and hypocrisy. The two terms are defined reciprocally: hypocrisy is everything human that resists the radical demand of faith. Adam, Eve, and Cain are hypocrites of a type that the Reformers know intimately from their everyday experience. As a social vice, hypocrisy would seem to be out of place in Eden. But the first couple are hypocritical in the existential (and for Calvin, primary) sense of refusing to know themselves before God. Thus, Calvin reads the fig leaves as a squeamish evasion: Adam and Eve "were led to repentaunce, neither with true shame, nor with serious feare ... the feeling of their evill was onely confused, and ioyned with dullnesse, much like unto a dreame in unquiet sleepe." 51 Yet we should not be too quick to judge them, Calvin says, because "we all are sicke of the same disease: for even at the first pricke of conscience, we tremble, are ashamed: by and by there creepeth in a favourable iudgement of our selves, which leaveth us to vaine toyes." 52

Calvin and Luther see hypocrisy less as a particular vice than as a way of being-ordinary and monstrous at the same time. So (following Calvin) does $\mathrm{Du}$ Bartas. The following passage on the ingrained moral evasiveness of the intellect is taken from a reflective chapter on the contemporary human meaning of the Fall titled "The Furies," which is sandwiched between two narrative chapters recounting Genesis 3 and 4:

But, for these Ills raigne in our intellect
(Which onlie, them both can and ought detect)
They rest unknown; or rather selfe-concealed;
And soule-sicke Patients care not to be healed...
Whereas our fond self-soothing Soule, thus sick,
Rubs her owne soare; with glozing Rhetorike
Cloaking her vice: and makes the blinded blaine.

${ }^{50}$ Of Luther's Old Testament commentaries, Bornkamm observes that "mankind always remains essentially the same" and that "the word of God and his own period of time were contemporaneous" $(18,19)$.

${ }^{51}$ Commentarie of John Calvine (see n. 18 above), 98.

52 Commentarie of John Calvine, 98.

${ }^{53}$ Du Bartas, Divine Weeks, “The Furies," 357-79, 11. 745-48, 753-55. 
To Calvin and Du Bartas, "hypocrites" are what "ordinary men" are to Christopher Browning: men capable of exterminating a Polish village out of no motive more compelling than group solidarity. ${ }^{54}$ Judith Shklar invokes the same adjective in her notion of "ordinary vices," namely, "the sort of conduct we all expect, nothing spectacular, nothing unusual." ${ }^{55}$ Such vices - "cruelty, hypocrisy, snobbery, treachery, misanthropy" - do not correspond with "the seven deadly sins of traditional Christianity." 56

A distinction is to be drawn between Luther and Calvin in respect of the ordinary. Luther saw the split between the Adamite group and the Cainite group in terms of the two churches, Reformed and Roman. The Cainites were the hypocrites, while the Adamites were Reformed. Calvin preferred to follow St. Augustine in viewing the Cainites as the founders of the "city of the world," which is to say, political economy or, in Carl Schmitt's view, politics per se. ${ }^{57}$ Of the two approaches, that of Augustine and Calvin is the more "modern." In the words of Patrick Downey, "Cain founds the first city. . . Politics is revealed for what it is, a pack of hidden murderers and thieves who appear to be law-abiding citizens out of fear rather than desire. Inside the heart of every citizen is a fugitive and wanderer who has no place to lay his head because he has exiled himself from his fellow man and creation. Outside, that same fugitive is a solid citizen who farms, plays well with others and obeys the law." ${ }^{28}$ This kind of thought underlies Hamlet.

\section{III}

My third proposition is that the insistently Reformed language of original sin is transformed in the course of its aesthetic assimilation to character. Shakespeare's version of Calvin's "hypocrite" is Claudius, but there is an "ordinary woman," too. Gertrude is a remarkably delicate blend of "ordinary" pathos and utter inscrutability. Her response to the accusation implicit in the Player Queen's vows of undying love- "The lady protests too much, methinks" (F

${ }^{54}$ Christopher Browning, Ordinary Men: Reserve Police Battalion 101 and the Final Solution in Poland (New York: Harper Perennial, 1993).

55 Judith N. Shklar, Ordinary Vices (Cambridge, MA: Belknap Press, 1984).

56 Shklar, 2.

57 Augustine, City of God, ed. and trans. David Knowles (Harmondsworth, UK: Penguin, 1972), book 15:1, 595-96; 15:17, 627. See also Bornkamm, 210-13. Augustine interprets the name "Cain" to mean "Possession" $(15: 17,627)$. Schmitt reads the Cain and Abel story as initiating the "enemy", a figure presupposing the existence of politics; see Jean-Claude Monod, "Hostility, Politics, Brotherhood: Abel and Cain as Seen by Carl Schmitt and Jacques Derrida," in Language, Ideology, and the Human: New Interventions, ed. Sanja Bahun and Dusan Radunovic (Farnham, UK: Ashgate, 2012), 95-112.

${ }^{58}$ Downey, Desperately Wicked, 103. 
3.2.222) - is superbly evasive. In her elusiveness and fundamental impenetrability, Gertrude speaks to the Pravum est cor omnium et inscrutabile in Jerome $17: 9$ of the Vulgate ("The heart is more deceitful than every other thing, and it is malicious"). ${ }^{59}$ At the same time, she raises the modern and entirely normal problem of "other minds." A comparison of Q1, Q2, and F is instructive. In Q1, this elusiveness is missing. The queen is a known quantity. On being clearly informed in the closet scene that her former husband has been murdered, she protests, "I never knew of this most horrid murder" (Q1 11.86). Afterward, she consistently sides with Hamlet against Claudius. Evidently, Q1's redactor was unable to tolerate a constitutive ambiguity in so important a character; the queen must declare herself for one side or the other.

In contrast, Gertrude is always a question mark in Q2 and F. She does not clearly acknowledge Hamlet's allegation of murder, condemn Claudius, or side with Hamlet against Claudius. On the other hand, she is not entirely of Claudius's party. She sits on the fence and stays there right up until the moment of her death. The question of her constitutive ambiguity ought to turn on the question of what she does or does not know about the murder. Hamlet's slightly muddled allegation, "As kill a king and marry with his brother" (Q2 3.4.27), which makes it sound as if Gertrude was the murderer, is found nearly identically in all three texts. But only in Q1 does the allegation force Gertrude to declare herself.

In psychological terms, it seems as if Gertrude's heart is not "made of penetrable stuff" (Q2 3.4.34), if being penetrated by an imputation implies that the accuser has a true picture of the mind or conscience being penetrated. The difference is between being confident that one can know another mind and admitting that one cannot. Q1 takes the first of these positions, while Q2 and F take the second. When Q1 Hamlet says, "I'll make your eyes look down into your heart / And see how horrid there and black it shows" (11.21-22), he implies that he has access to what is in Gertrude's heart. He knows what color her heart is and why. But in Q2 and F, he has no such access. Q1's imagery of blackness and taint is expressed by Gertrude, who sees "black and grained spots" ( $F$ 3.4.81) or "black and grieved spots" (Q2 3.4.87-88) in her soul and guards the secret of what they are and how they got there. So innovative and tactful a character sketch would seem at odds with the homiletic idiom of sin and hypocrisy. However, Hamlet hangs the sign of "Frailty" around Gertrude's neck in all three texts, perhaps echoing the Eve of Sylvester's Du Bartas, the "fraile treacherous bride", with her "frail brest" and her "simple frailty." ${ }^{60}$ Gertrude is actually more Eve-like in Q2 and F because these texts foreground the issue of concupiscence

${ }^{59}$ See the array of parallel readings of Jeremiah 17:9 in Bornkamm, 221.

${ }^{60} \mathrm{Du}$ Bartas, Divine Weeks, “The Imposture," 1l. 423, 281, 426. In Du Bartas, Eve's frailty is explicitly imagined as a susceptibility to persuasion-a strong suit of Claudius in Hamlet. 
and sideline her complicity in murder. Gertrude's "black and grained spots" speak the language of sin, not crime-the primal sin of Eve.

For all this, it is mainly in her son's language that we sense an overtly homiletic tone of pious horror. Hamlet's hysterical reaction to Gertrude (and to Ophelia in the nunnery scene) is typical of the Reformation's anxiety about sin, as distinct from the Reformation theology of sin seen in the commentaries on Genesis. It is the tone of spiritual crisis in Puritan autobiography, a burgeoning consciousness of sin coupled with a despair of salvation. The play itself does not recoil from Gertrude or condemn the love between Gertrude and Claudius. Shakespeare wishes us to register Hamlet's account in the closet scene as both hysterical and reductive (in the manner of Iago's account of love as "merely a lust of the blood and a permission of the will" [Othello, 1.3.333]). The problem here is not exclusively with Hamlet so much as with the difficulty posed by an ethical perspective on original sin. Ethics, as Kierkegaard notes in a brilliant aperçu, is driven to hysteria by original sin: "As soon as sin is actually posited, ethics is immediately on the spot, and now ethics follows every move sin makes." Understanding is not the strong suit of ethics because "ethics is never observing but always accusing, judging and acting" "62 This results in formulations such as the Smalcaldic article, ${ }^{63}$ describing "hereditary sin" as "so profound and detestable a corruption in human nature that it cannot be comprehended by human understanding, but must be known and believed from the revelation of the Scriptures." ${ }^{64}$ The statement is confused, insists Kierkegaard, for assuming "the role of an accuser, who with an almost feminine passion ... is now concerned only with making sinfulness and his own participation in it more and more detestable, in such a manner that no word can be severe enough to describe the single individual's participation in it." ${ }^{\text {65 }}$ This is an apt comment on Hamlet's tone in the closet and nunnery scenes, in both of which (ironically) he is more often taxed with misogyny than with hysteria.

In Gertrude, Shakespeare has taken the radically normalized category of hypocrisy in the Reformers seriously as a premise of characterization. By normalizing the agents of Genesis, the Reformers-especially Calvin-wanted to

${ }^{61}$ Søren Kierkegaard, Kierkegaard's Writings. Vol. 8, Concept of Anxiety: A Simple Psychologically Orienting Deliberation on the Dogmatic Issue of Hereditary Sin, ed. and trans. Reidar Thomte (Princeton: Princeton UP 1980), 22.

62 Kierkegaard, Concept of Anxiety, 22.

63 The Smalcaldic Articles represent Luther's formulation of the core articles of his faith for use by the Smalcaldic League of German Protestant states in 1537. They were incorporated virtually unchanged in the Formula of Concord of 1577, the formal and definitive early modern expression of Lutheranism.

${ }^{64}$ Kierkegaard, Concept of Anxiety, 26.

${ }^{65}$ Kierkegaard, Concept of Anxiety, 26. 
shock their readers into acknowledging the primal fallibility of normal lives. Du Bartas follows Calvin's lead closely in "The Furies" when reflecting on the fallen condition of ordinary humanity. Shakespeare too follows this Calvinist logic, but with a brilliant twist: building his characters on an assumption of normal crookedness, he suspends judgment while inviting complicity. If Gertrude and Claudius are judged at all, it is only by their fellow hypocrites, the audience.

Claudius is Shakespeare's version of Cain, or Calvin's "ordinary man." He is a conscientious and sympathetic villain, unusual in a genre specializing in unconscionable Machiavels. He will do what is necessary to become king, and then do what is necessary to stay king. But far from gloating, he is tortured by wrong once he has done it. Two aspects of Calvin's portrait of Cain are suggestive of Claudius-hypocrisy and conscience. That Cain should be explained in terms of the same moral psychology as Adam and Eve is a striking feature of Reformed commentary in both Calvin and Luther. There is no sharp line between the murderer and the merely fallen, the former being an exacerbation of the latter. Cain's evil only seems to begin with his murderous jealousy of Abel; it has begun already in the "uncleannesse of his heart." ${ }^{66}$ Cain is a version of the Eve paradox, where primal wickedness is commonplace: "In the person of Caine we have an image of a wicked man painted forth unto us, who notwithstanding his wickednesse will be counted iust"; such men "would be at peace with God after their owne will." ${ }^{67}$ Cain pays lip service to God, but does not "yeelde and bende him selfe wholly unto him." ${ }^{68}$ Hypocrisy comes from knowing oneself before men, rather than before God. To all intents, it is the ethical signature of original sin, a perpetual veto of the natural law originally inscribed in the human heart. Calvin wants his portrait of Cain to shock; the reader must feel her existential continuity with the first murderer. She is a potential murderer, as it were, by being a real hypocrite.

Hypocrisy, in all of these senses, is Claudius's keynote. It is not just that he is more fox than lion or may "smile and smile and be a villain" (F 1.5.108). To judge him from the outside is something that the play (as distinct from Hamlet) never does. Claudius is less a villain than a slider between moral and emotional claims, a finder-out of mirth in funeral and delight in dole. He emerges indirectly in a multitude of details, large and small. We can begin with a small (and traditionally puzzling) detail found only in Q2 and F-the care Claudius lavishes on his description (F 4.3.67-76) of the horsemanship of Lamord (as he is called in

${ }^{66}$ Commentarie of John Calvine, 141. Compare the moment of the sacrifice in Du Bartas, where Abel,"with zealous cry / Cleaves bright Olympus starrie Canopie," Cain,"with fained lips ... lowd-resounded / Hart-wanting hymnes, on selfe-deseruing founded” (11. 287-88, 289-90).

${ }^{67}$ Commentarie of John Calvine, 132.

${ }^{68}$ Commentarie of John Calvine, 131. 
Q2), the Norman who praised Laertes's skill with the rapier. Why should this detail be drawn out at such length? Philip Edwards suggests that Claudius's love of horsemanship parallels Hamlet's love of the theater. ${ }^{69}$ Michael Long explains it as a brief moment of Philistine escapism, indulged in by both men, from the troubling business of murder. ${ }^{70}$ These attractive hypotheses become more substantial if the passage is taken as echoing Du Bartas's topos of Cain's horse. A long passage in "The Handicrafts" describes Cain's taming of a beautiful horse. In part, Cain wishes to escape vengeance for the murder of Abel; he also wants to distract himself from the agonies of a bad conscience. ${ }^{71}$ Shakespeare comes closest to echoing Du Bartas in the detail where Lamord

$$
\text { grew into his seat }
$$

And to such wondrous doing brought his horse

As had he been incorpsed and demi-natured

With the brave beast.

$$
\text { (F 4.3.71-74) }
$$

In Du Bartas, Cain is said to have"so done with time-grace-ordred skill, / As both had but one bodie and one will."72 What is most interesting about this resonance is the moral status of horsemanship in Du Bartas. Mastery of the horse is bad when serving a bad conscience and a bad cause (the horse serves for conquest, as well as flight); yet it is good as a necessary and entirely normal aspect of man's conquest of nature. Simon Goulart, the Genevan Calvinist minister whose notes to Du Bartas still form the backbone of learned commentary, addresses this ambiguity in his discussion of the line "Cain, as they say, by this deep feare disturbed": "The poet intending to shew that Cain and his race were a people addicted to the world (who had no thought but of the commodities of the earth) by a gentle invention, attributed to Cain, a man stout and strong, a man that had opportunity and leisure, seeking after nought else, but that which might give him a truce to the warre, which was within his evill conscience, endevored himself to back $\&$ tame Horses, this exercise being truly proper to dispost men, hardy and strong in hand, and whose hearts were thorowly settled on this world."73 Acknowledging that horsemanship is undeniably a good, Goulart goes on to allow, "If those that have holy thoughts, addict themselves to master such generous beasts ... it is for necessity, and when as pleasure is united thereunto ... yet so as they have that thing always in their memory, which is the princi-

${ }^{69}$ See Philip Edwards, ed., Hamlet (Cambridge: Cambridge UP, 1985), 207.

${ }^{70}$ Long, 134.

${ }^{71}$ Du Bartas, "Handy-Crafts," Divine Weeks, 11. 381-476.

${ }^{72}$ Du Bartas, "Handy-Crafts," Divine Weeks, 11. 467-68.

${ }^{73}$ Simon Goulart, A Learned Summery upon the Famous Poem of William of Saluste, Lord of Bartas (London, 1621), 135. 
pal."74 A sidelight is thrown on this ambiguity in a 1618 sermon by Samuel Ward that likens a good sermon to a good horse, one more effective than elegant: "You shall sometimes see an excellent horse of shape and colour, having many of those markes Du Bartas describes in Caine's supposed horse; which yet wanting mettle hath beene of little worth and lesse use." ${ }^{.75}$ In other words, the topos is as morally ambiguous in Du Bartas as it is in Hamlet: talking about sports is an innocent diversion for Claudius and Laertes and a salve to the evil scheme they are hatching. Nothing could be more normal for aristocrats such as Claudius and Laertes than a love of fine horsemanship. But as the vaguely sinister name "Lamord" suggests, the normality is ominous: the two men (who have been circling each other warily up to this point) connect through this shared taste and seal their alliance.

A second and weightier example of Claudius's bad normality is his failure to stop Gertrude's drinking from the poisoned cup. As far as Claudius is concerned, Gertrude is not expendable. But Claudius is incapable of seizing the one moment that he has to dash the cup from Gertrude's hands because that would mean exposure. The pain and confusion, the shame and futility of this moment are richly understated. We have but to fill in the dots, much as Luther says of the gnomic verbal form of Genesis 4 when Cain "rose up" against Abel: "Among historical accounts there is one about a painter who painted the story of Iphigenia at the moment she was about to be sacrificed. To each of the spectators he assigned his own particular demeanour, expressive of his sorrow or grief. But the head of the father, who was present at the scene, he covered up, because he held that the depth of the father's feeling could not be expressed in a painting." 76 The father of course is Agamemnon, and his emotion is beyond depiction because it is so deeply agonized. Luther goes on to say that "Moses really did the same thing ... he suggests by dots, as it were, situations that cannot be expressed in words." 77 One of Luther's great strengths as a commentator on the Old Testament compared to Calvin is the aesthetic intelligence of his use of tragedy as a paratext. That Cain is a hypocrite does not mean that he is less than fully human or less an object of human sympathy. As for Moses, Luther attributes his succinctness partly to artistic tact and partly to depth of feeling: there were moments in which Moses literally could not see the page for weeping. ${ }^{78}$

74 Goulart, 135.

${ }^{75}$ Samuel Ward, A Coale from the Altar (London, 1628), 70. What Ward has in mind is less a show pony (of the type chosen by Cain and envisaged by Claudius and Laertes) than a workhorse. Ward's opposition to aristocratic elegance is probably code for an antiprelatical bias.

${ }^{76}$ Luther, Lectures on Romans, 25:279-80.

77 Luther, Lectures on Romans, 25:280.

${ }^{78}$ Bornkamm, 37-38. 
The second feature linking Claudius to Calvin's Cain is his conscience. For Calvin, conscience is the psychological and spiritual complement to hypocrisy. Because of its inaccessibility, its capacity to hide in the law, hypocrisy always outstrips human sanction. Conscience alone can track the hypocrite through all the "lurking corners and by turninges" of his heart. ${ }^{79}$ Typically, the hypocrite resists his conscience but for this very reason, he will be "feered and tormented with secret burning yrons." 80 The pain of conscience, Calvin tells us, is a foretaste of the final judgment, the only way that hypocrisy is punished in this world. "Conscience" is a keyword for Hamlet as much as it is for Claudius, but only Claudius has a truly Calvinistic dread of it. Hamlet (as we shall see) disputes "cases of conscience" where conscience might point two ways, ${ }^{81}$ while Claudius fears conscience as the infallible register of his depravity."How smart a lash that speech doth give my conscience!" (F 3.1.50), Claudius says of a Polonius commonplace about hypocrisy. In the prayer scene (Q2 3.3.36-72), Claudius is excoriated by his conscience because he is incapable of repenting of the sins with which his conscience upbraids him. Calvin, I think, would have found nothing to complain of in this speech, perhaps not even the empathy that Claudius's ordeal arouses in the audience. Before God, the murderer's plight is a version of our own. Of course, Claudius never lets conscience bar his way to new crime. When Laertes boasts that he will "cut" Hamlet's "throat i'th' church" (F 4.3.99), Claudius answers, "No place indeed should murder sanctuarize. I Revenge should have no bounds" (F 4.3.100-101). What starts out as a case of conscience (if it is sacrilegious to take revenge in the church, is it legitimate to take it somewhere else?) ends in a brilliantly cynical conceit.

Elsinore is full of ordinary men and women. Reading this society through Schopenhauer's sin-soaked idea of tragedy, Michael Long characterizes it as "philistine," in the sense of willing a low moral horizon upon itself. 82 "Ordinary" suits Elsinore better, as a concept truer to Schopenhauer and closer to original sin in the Reformed theological key. "Ordinary" is more akin to the twenty-first century than the later twentieth, when "philistinism" seemed a remediable vice, something that could be fixed by moral earnestness and education..$^{83}$

We have already considered four Elsinoreans. It is worth briefly considering several more: Polonius, Rosencrantz and Guildenstern, and the fictional occu-

${ }^{79}$ Commentarie of John Calvine, 138.

${ }^{80}$ Commentarie of John Calvine, 138.

${ }^{81}$ In "The Case of Hamlet's Conscience," Studies in Philology 76 (1979): 127-49, Catherine Belsey discusses Hamlet's testing of conscience against a tradition of Calvinist casuistry exemplified by William Perkins's "cases of conscience" (133).

${ }^{82}$ Long, 123-29.

${ }^{83}$ For two books witnessing the shift I suggest here, see Downey; and John Gray, Straw Dogs: Thoughts on Humans and Other Animals (London: Granta, 2002). 
pants of Elsinore's graveyard, the avatars of "Cain's jawbone" (F 5.1.77). Polonius has been a troubling figure for critics since the 1930s. For anti-Hamlet critic Eleanor Prosser, he is a harmless dotard, whose killing is very much to Hamlet's discredit. ${ }^{84}$ For Jan Kott, he is head of the secret police, and his death is positively welcome. ${ }^{85}$ If we consider Polonius ordinary, we can decide between these positions because the moral ambiguity is inbuilt. Deviousness may be second nature to Polonius, but he is capable of reproving himself for this fault and paining Claudius with his simple honesty (F 3.1.46-49). He is capable, too, of that famously pious admonition to a son (F 1.3.55-81). We can almost imagine Plato referring to this speech in the Gyges section of The Republic when he remarks on the bad faith of the genre of paternal advice: "Fathers, when they address exhortations to their sons ... urge the necessity of being just, not by praising justice itself, but the good repute with mankind that accrues from it, the object that they hold before us being that by seeming to be just the man may get from the reputation office and alliances and all the good things that Glaucon just now enumerated as coming to the unjust man from his good name." ${ }^{86}$ To read Polonius's advice to Laertes with Plato's eye is to sense the underlying note of calculation, especially where friends are concerned.

Rosencrantz and Guildenstern seem to present a sterner test of ordinariness, in that we are virtually invited to applaud their demise. Hamlet's assertion- "They are not near my conscience" (F 5.2.58) - challenges not just Horatio but also the audience. Prosser blames Hamlet for ruthlessness because he could not be sure that his old friends had understood the full meaning of their visit to England. ${ }^{87}$ Kott doesn't mention them specifically but we can guess what he might have said from his attitude to Ophelia, who has to be sacrificed as "part of the mechanism." 88 In the end, "indifferent children of the earth" (F 2.2.225) sounds right: Rosencrantz and Guildenstern are the flawed progeny of Adam and citizens of the Cainite "city of the world." Like Gertrude, they are portrayed with tact. There are no signatures of evil, no villainous asides or confidences; they are simply on the make. Stoppard was within the bounds of plausibility to imagine them as victims, rather than as accomplices. The manner of their disposal should trouble us. If people like this are to be killed, then where does the killing stop?

Even the burial plots of Elsinore are crooked. Why does the skull thrown from the grave by the sexton's shovel remind Hamlet of "Cain's jawbone, that

${ }^{84}$ Eleanor Prosser, Hamlet and Revenge (Stanford: Stanford UP, 1971), 194.

85 Jan Kott, Shakespeare Our Contemporary, trans. Boleslaw Taborski (London: Methuen, 1964), 49-50.

${ }^{86}$ Republic, in Dialogues, 610 (sections 362-63).

87 Prosser, 205.

${ }^{88}$ Kott, 51, 59. 
did the first murder" (F 5.1.77)? In tradition, if not in Genesis 4, Cain wields the jawbone of an ass to murder Abel. Here, the jawbone is Cain's own. But that too-the wordplay seems to insist-is an effective weapon. If Cain's hypocrisy and his role in founding "the city of the world" are borne in mind, there is a real connection between "Cain's jawbone" and the former Cains imagined by Hamlet. Each portrait in this rogue's gallery is linked by the idea of devious speech. Like Calvin's hypocrite, the politician was "one that could circumvent God" (F 5.1.79). The courtier praised a horse "when he meant to beg it" (F 5.1.83-84). The lawyer had "quiddits" and "quillets," "cases ... tenures and ... tricks" (F 5.1.97-98). The "great buyer of land" had "his statutes, his recognizances, his fines, his double vouchers, his recoveries" and "conveyances of his lands" (F 5.1.102-4, 108). Such purchasing might resonate with the inscrutable "election" by which Claudius acceded to the throne. In both cases, the suggestion is of a shady normality-"the corrupted currents of this world" (F 3.3.57) — processes that are crooked but legal.

It is just this image of evil that haunts Hamlet. The "unworthy" scorners of "patient merit" (F 3.1.74) and those who wield the "insolence of office" (F 3.1.73) anticipate the rogue's gallery of the graveyard, down to the fine lady whose "inch thick" painting (F 5.1.189) allies her with Claudius's "most painted word" (F 3.1.53). Whenever Hamlet generalizes from his immediate dilemma, his mind slips into the thought of normal injustice, oppressiveness, and corruption. Revenge is no answer to this, unless in the witty touch where Cain's skull is jowled to the earth by the gravedigger, one of those who "hold up Adam's profession" (F 5.1.31). This may be a joke on Calvin, whose commentary pointedly prefers the earthy occupations of the Adamites to the sophisticated occupations of the Cainites (a primitivism mocked in Luther's commentary). Alternatively, the joke about Adam's "arms" ("Why, he had none" [F 5.1.34]) gestures toward the medieval anthem of peasant egalitarianism, "Whan Adam dalf, and Eve span, / Wo was thane a gentilman?" 89

\section{IV}

What must Hamlet do, mired in sin and dedicated to revenge? My proposition here is that the Reformation is as much a part of the solution as the problem. Linked by the Cain-Claudius symbolism, the themes of original sin and revenge mutually compound the Catch-22 character native to each. Where a heightened consciousness of original sin provokes ethical horror, it also demoralizes because one can do nothing to redress what one loathes in others, given

89 Thomas of Walsingham, Historia Anglicana, quoted in R. B. Dobson, The Peasants' Revolt of 1381 (Eastbourne, UK: Palgrave, 1983), 374-75. 
that one is loathsome oneself. Obsession with original sin is a trap from which Hamlet can escape only by a leap of faith. The revenge dilemma is equally traplike: Hamlet must restore justice by destroying Claudius but do so in a way that does not taint his mind or involve his mother. Initially, the Ghost's revelations seem to offer a way out of the oppressiveness of "sallied flesh" (Q2 1.2.129), because at last Hamlet has what Paul Ricoeur calls a "myth of accusation." 90 Claudius is now criminal, as well as merely loathsome. Yet the respite is illusory. The only evidence against Claudius is the Ghost's testimony, and even Hamlet will not take the Ghost at his word. ${ }^{91}$ Finally, although Hamlet establishes Claudius's guilt to his own satisfaction, this still does not amount to proof. Claudius has covered his public tracks so well that he is vulnerable only to a secret revenge, which is to say, the tactic of Gyges and the trap of original sin.

For the most part, Hamlet pursues a rational, moral, and courageous course. To be sure, he lapses into moral hysteria, Senecan bloodthirstiness, and the mood of the "To be or not to be" soliloquy (F 3.1.56-88), momentarily taking up residence with Schopenhauer in what Lukacs called the "Grand Hotel Abyss." 92 But Hamlet is purposeful, too, establishing Claudius's guilt to the point of certainty. The gains are rarely lasting. Thus, the success of the Mousetrap leads to one of Hamlet's worst moments-his vengeful gloating over the praying Claudius - and a catastrophic error-the stabbing of Polonius. Yet within the limits of his mental, moral, and physical strength, Hamlet pursues the challenge of what he must do. He never gives in to the enemy and does not give way to despair.

The most productive response to both dilemmas is Hamlet's dialogue with conscience: can he-in conscience-resist tyranny to the death? Can he rid himself of spies like Rosencrantz and Guildenstern? Should he address a wider spectrum of injustice (the scorning of "patient merit" and so on)? Can he just do away with himself? What exactly is conscience anyway? Must it be reactive or can it be proactive? Must it be monitory or can it be muscular? In posing these

\footnotetext{
${ }^{90}$ Paul Ricoeur, The Conflict of Interpretations, trans. Peter McCormick (London: Continuum, 2004), 332-50.

91 The moral authority of the Ghost is a vexed question. To Prosser, he is demonic. (100-116). But it is significant that Hamlet should second-guess the Ghost's testimony with the Mousetrap. Shakespeare treats the Ghost with a moral skepticism similar to that of Seneca. Purgatory is a good indicator of this Ghost's moral level. Hamlet's compulsive affinity with Pyrrhus suggests a parallel with the bloodthirsty ghost of Achilles in Troades (whose very existence, let alone moral authority, is questioned by the chorus). See Troades, in Seneca's Tragedies, ed. Frank Justus Miller, 2 vols. (London: William Heinemann, 1960), 1:371-408.

92 Georg Lukacs describes Schopenhauer's system as "a beautiful hotel, equipped with every comfort, on the edge of an abyss, of nothingness, of absurdity [in which] the daily contemplation of the abyss between excellent meals or artistic entertainments, can only heighten the enjoyment of the subtle comforts offered." See The Theory of the Novel (London: Merlin, 1971), 22.
} 
questions, Hamlet engages most fully with Reformed-especially Calvinistthinking, because it is here that the proactive dimension of conscience is most adventurously evolved.

Conscience is encountered first in its cowardly form: "Thus conscience does make cowards of us all" (F 3.1.83). The great soliloquy raises options- "to take arms ... against a sea of troubles" (F 3.1.59) or commit suicide-but it discourages both. The legitimate course is cowardly. Hamlet echoes the Elizabethan Homilies and Reformed commentary on Paul's epistle to the Romans, among other contexts. ${ }^{93}$ The homilies against Disobedience and Wilful Rebellion make it clear that our sinfulness forfeits any expectation of just treatment in this world. ${ }^{94}$ Unjust magistrates are to be endured, just as spectacularly evil rulers like Saul, Tiberius, and Nero were endured by David, Jesus, and St. Paul. ${ }^{95}$ Calvin enjoins us to "suffer iniuries" with "a quiet minde," trusting to providence to vindicate innocence. ${ }^{96}$ Against Romans 13:5, preaching obedience "not for fear of vengeance only: but also because of conscience," Tyndale adds the marginal comment: "Though thou were of power to resist the power, yet were thou damned in thy conscience if thou didest it, because it is against God's commandment." ${ }^{\text {"7 }}$ The equivalent gloss in the Geneva Bible largely concurs: "We must obey the Magistrate, not onely for fear of punishment, but much more because that (although the Magistrate hath no power over the conscience of man, yet seeing he is Gods minister) he cannot be resisted by any good conscience." 98 In the Homilies, however, to endure out of prudence rather than conscience is still preferable to the alternative of rebellion. The title page of An Homilie against Disobedience and Wylful Rebellion, published separately in 1570, juxtaposes "Iusticia" (whose right hand holds a sword) with "Prudencia" (holding a serpent writhed about her left arm)..$^{99}$

Hamlet next invokes conscience in the Fortinbras soliloquy (Q2 4.4.31-65). But whether one should seek greatness honorably or rightly is left open. For all his reservations about Fortinbras's recklessness and ruthlessness, Hamlet clearly envies him. The next invocation of conscience-Hamlet's boast that Rosencrantz and Guildenstern are "not near my conscience" - we have

${ }^{93}$ Belsey, "The Case of Hamlet's Conscience," traces the origins of the standard association of conscience with cowardice to a generic opposition of conscience and wrath in the morality tradition. Her discussion of the meaning of conscience in Hamlet is situated mainly between this and the later tradition of Calvinist casuistry.

94 Sermons or Homilies, 4th ed. (Oxford: Clarendon Press, 1841), 468-516.

95 Sermons or Homilies, 91-94.

${ }^{96}$ Commentarie of John Calvine, 141.

97 Tyndale's New Testament, 238.

${ }^{98}$ Geneva Bible, To the Romanes, 13:7, 78.

99 An Homilie against Disobedience and Wylful Rebellion (London, 1570), frontispiece. 
partly examined. What we can note, however, is the surprising turn taken by the theme. Where conscience has previously (if reluctantly) been deferred to, it is now conscripted aggressively to the dispatching of Hamlet's old schoolfellows over Horatio's implicit demur: "So Guildensterne and Rosincrance go to't' (F 5.2.56).

The final invocation of conscience is a true crux, crucial to our reading of the outcome and deeply ambiguous. Rehearsing a catalogue of Claudius's villainies to Horatio, Hamlet rhetorically if somewhat obscurely asks in Q2: "Does it not, think thee, stand me now upon? / He that hath killed my King ... / Is't not perfect conscience?" (Q2 5.2.62-63, 66). F's version of the suggestion is both sharper and longer:

\section{Is't not perfect conscience}

To quit him with this arm? And ist not to be damned

To let this canker of our nature come

In further evil?

(F 5.2.67-70)

The difference in the texts is critical. In Q2, the rhetorical question is unambiguous for all its obscurity; in $\mathrm{F}$, the added precision entangles itself in an implicit refutation. Hamlet wants to say that it is damnable to let a criminal remain on the throne, but his identification of the king with "this canker of our nature" that must not be allowed to "come / In further evil" resonates powerfully with the "canker" motif threading through the play. This includes Claudius's invocation of the same motif shortly before to describe Hamlet himself ("But to the quick of thulcer- / Hamlet comes back" [Q2 4.7.121-22]). With this parallel, Hamlet's invocation embraces his own canker or innate sin. Hence, the proposition virtually disables itself. Since the "canker" passage appears in the later and normally terser F, rather than Q2, ${ }^{100}$ it would seem to represent the definitive form in which the question is put. Without the additional material in $\mathrm{F}$ as disclaimer, the provocativeness of Hamlet's question to Horatio is too great. Hamlet could easily be understood as inciting Horatio (and thus the audience) to "wylful rebellion." Characteristically, Horatio answers noncommitally ("Why, what a king is this!" [5.2.62]). ${ }^{101}$ Neither toady nor conspirator, Horatio walks a fine line. His exemplary judiciousness - "'en as just a man / As e'er my conversation coped withal" (F 3.2.52-53) —demands no less.

100 "Canker" is capitalized in F (5.2.69; through-line number 3573).

${ }^{101}$ Belsey reads the "perfect conscience" passage as a moral injunction "to prevent further villainy" "The Case of Hamlet's Conscience," 144). Horatio's "outraged reaction ... is I think the audience's: Claudius is not a fit ruler" (144). Lars Engel reads Horatio's response as noncommittal, but keys "perfect conscience" to Hamlet's perception of Horatio in "How Is Horatio Just?" in Shakespeare Quarterly 62 (2011): 256-62, esp. 260. 
There is a further significance to the extraordinary liberty taken with the concept of "conscience" at this point. In claiming a "perfect conscience" (emphasis added), Hamlet gestures toward a specifically Reformed discussion of both the nature and the discretion of conscience. If conscience were about keeping one's word, then is credit not partly due to Herod for presenting the head of John the Baptist to Salome in order to keep his oath? No, argues the Geneva gloss to Matthew 14.1: Herod is "an example of tyrannous vanitie, pride and crueltie, and to bee short, of a courtly conscience." ${ }^{102}$

Keeping an oath has much to do with the nature of the oath itself. Courtly oaths have no necessary moral or religious character. What, then, of conscientious observance of what is truly lawful? Even this is not what conscience really means. In Romans 14:20-23, Paul puts it this way: "Destroy not the work of God for a little meat's sake. All things are pure: but it is evil for that man, which eateth with hurt of his conscience... . Hast thou faith? have it with thyself before God. Happy is he that condemneth not himself in that thing which he alloweth. For he that maketh conscience, is damned if he eat: because he doth it not of faith." ${ }^{103}$ For Paul, the law is not binding of itself unless it is taken to be binding in a given case. The law binds only "of faith." For example, although dietary observance is subjective, breaking a dietary rule is impious when done with an unquiet conscience. Simply to "do against conscience is damnable" as a marginal note has it, "and all that is not of faith is sin." "Making conscience" is a perilous activity even when the law to be complied with is illusory. ${ }^{104}$

How then can Hamlet claim a "perfect" conscience in the imponderable case of regicide? The answer may lie in the radicalism of grounding conscience in faith. The Geneva gloss to Romans 5:1 ("Then being iustified by faith") reads, "We are iustified with that, which truly appeaseth our conscience before God: but faith in Christ doeth appease our conscience and not the Law ... by faith we are iustified and not by the law." 105 This is exactly what "perfect" conscience means: a proactive conscience founded on faith and guided by it. To the Reformers, the Bible and the Old Testament in particular abounded in examples. The most noteworthy of these was the trickery of Esau by Jacob and Rebecca. Of Jacob, Luther remarked, "When God truly commands saints and faithful men to do something, it is without any doubt holy and permissible"; of his mother, he wrote: "Rebecca handled the matter with skill, with cleverness, and with the most beautiful fraud, and handled it according to the will of God, who granted a happy ending in a matter so difficult and so filled with inherent

102 Geneva Bible, 9.

103 Tyndale's New Testament, 239-40.

104 Tyndale's New Testament, 239-40.

105 Geneva Bible, 73. 
dangers." 106 As Bornkamm remarks, these are "historical examples, showing that faith may break the law." 107 This is the message of Jacob and Esau, an anonymous comedy published in 1568 expounding the theology of predestination: the gulling of Esau (and indeed Isaac) is justified by a faithful insight into divine election and reprobation (where Jacob is aligned with Abel, Esau is aligned with Cain). ${ }^{108}$ If faith is enough to justify Rebecca's trickery of Esau, would it not also justify Hamlet's disingenuous apology to Laertes for having killed Polonius (the speech in which Brljak finds the damning invocation of Lamech or Lameth) ${ }^{109}$ We are invited to weigh one possibility against the other.

Between the intense and quasi-Reformed moment of "perfect conscience" ( $F$ 5.2.67) and the following one of the "special providence in the fall of a sparrow" (F 5.2.167-68) is the extended comic interlude in which Osric delivers the challenge. Reading past this interlude, most pro-Hamlet readers prefer to telescope the two moments at either end, taking the "special providence" moment very much as a consolidation of the "perfect conscience" moment (emphasis added). Certainly the transcendental language of each bespeaks a strongly Reformed conception of justice. But we could equally read the two moments against each other. Indeed, I take the Osric interlude as signaling a disjunction between the moment at which conscience is frog-marched into line with necessary violence, and a simple "readiness" to await whatever providence may send one's way. ${ }^{110} \mathrm{In}$ this reading, Hamlet is "ready" only when he has dropped the attempt to yoke conscience to his project of revenge. (Horatio's non-assent to Hamlet's proposition suggests why that is a nonstarter.) At issue here is faith itself. The Hamlet who tries to conscript conscience is not notably religious, let alone a true Protes-

${ }^{106}$ Quoted in Bornkamm, 22, 24.

107 Bornkamm, 25.

${ }^{108}$ See $A$ nevve mery and vvittie comedie or enterlude, newely imprinted, treating vpon the bistorie of Iacob and Esau ... (London, 1568). The furious Esau regrets that "God was angry with Caim for killing Abell: / Els might I kill Iacob meruellously well" (sig. F4v) and is warned by Rebecca: "Beware by the example of Caym, I thee rede / That thou bringest not the Lorde's curse vpon thy head." (sig. G3r). Resonances in The Merchant of Venice suggest that Shakespeare knew this play. The blessing Gobbo seeks of his blind father (2.2.85-96) burlesques the blessing of Isaac on Jacob (disguised as the hairy Esau). Portia's expression that Bassanio is "dear bought" (3.2.311) echoes this same expression in respect of the pottage for which Esau sells his birthright; see A nevve mery and vvittie comedie, sigs. C2 and D1.

${ }^{109}$ Brljak (see n. 13 above). See also Thompson and Taylor's comment (Q2 5.2.204-21n): "This apology to Laertes ... has struck editors and commentators since at least Johnson in 1765 , as disingenuous."

${ }^{110}$ Belsey takes Hamlet's decision to kill Claudius as justified but also tainted. Although "as ethically scrupulous as it is possible to be," Hamlet "is inevitably corrupted by his mission" ("The Case of Hamlet's Conscience," 148). On the ethical dilemma presented by dirty hands in a good cause, see John M. Parrish, Paradoxes of Political Ethics: From Dirty Hands to the Invisible Hand (Cambridge: Cambridge UP, 2007). 
tant believer. We find ourselves hoist on the same petard-that of a faux Protestant piety-feared by Bradley, Sinfield, and Edwards. How is it credible that Hamlet should suddenly reach for the patently Calvinist category of "special providence" or Q1's "Predestiuate providence" (Q1 2.126)? It is tempting to say that what separates these two moments is an unseen leap of faith. Equally, the Osric interlude may signal Hamlet's change of mind. The interlude, present in some form in all three texts (Q2 5.2.68-162), presents a difficulty equivalent to that of the Lamord passage; its length and elaborateness (particularly in Q2) are not justified by its functionality. Part of the reason for this impression is a failure to appreciate its resonance with the Lamord passage. Osric is a kind of double to Laertes in his devotion to fencing, his courtliness, and his use of technical language (the term "carriages" [F 5.2.116-18], for example, which Hamlet professes not to understand). Osric positively embodies the courtly enthusiasm infusing Claudius's account of Lamord. Laertes in turn is linked to Lamord, both as an admirer (calling him "the brooch, indeed, / And gem of all our nation" [F 4.3.78-79]) and as the reported object of Lamord's own admiration (F 4.3.80-88). As Lamord is to horsemanship, so Laertes is to fencing. What Hamlet so disdains in Osric is not just his idiocy but the courtly emulation that he represents, the ethic of which Hamlet himself (according to Ophelia [F 3.1.151-61]) was once a conspicuous example. Revenge is equally part of this courtly ethic. Honor must be satisfied at all costs. The Osric episode is relevant to Hamlet's change of mind and equally relevant to the abrupt contrast posed by the Calvinist "special providence" to which Hamlet now submits himself.

The result that Hamlet awaits at the hands of Providence is undeniably ominous. What "will come" (F 5.2.170) is heavy with the dread Hamlet already feels at conceding the initiative to Claudius: "Thou wouldst not think how ill all's here about my heart" (Q2 5.2.190-91). In these circumstances, blind faith is surely fatal, as Hamlet knows. Yet it must also be said that the event proves Hamlet's strategy to have been right, if the crucial issue is to end the Catch-22 situation whereby Claudius cannot be brought to justice. In her last moments, Gertrude makes her first and only moral decision by unmasking Claudius and putting an end to his public immunity. It is as if Gyges's ring had been snatched away from him. Laertes seconds her accusation. Claudius now stands naked not just before Hamlet but also before the shadowy collective that elected him king. Although a cry of "Treason, treason!" is raised by "All," as the First Folio puts it (F 5.2.277n), no one steps forward in Claudius's defense: "O yet defend me, friends. I am but hurt" (F 5.2.278). In principle, the violence of the conclusion can be seen as lawful, rather than impulsive (as Adorno thought) or vengeful (as most leveling critics suppose) ${ }^{111}$ It is possible

${ }^{111}$ Adorno (see n. 3 above), 233-34 and n2. 
that Hamlet dies "elect" in a double sense as the rightful prince of Denmark and the Pauline athlete whose final deference to providence invites an opportunity for lawful violence that he could never have foreseen if left to his own devices.

If this reading avoids the trap of the "leveling" reading (that of the antiHamlet school and the original-sin school) it steps willfully-not unlike Hamlet himself-into the trap of the religious reading; welcomed by Kierkegaard but suspected by Sinfield and Edwards. One issue with such a reading is to make the play seem less a mirror of our own times than Jan Kott insisted that it was. While the political fervor of Kott's reading (along with his predilection for moral blacks and whites) may have waned considerably, we are-as Simon Critchley reminds us-no more truly religious in the early twenty-first century than we were fifty years ago when Shakespeare Our Contemporary appeared in English. ${ }^{112}$ We are however at an historical juncture far more receptive to what one might loosely call "original-sin thinking" than at any stage in the last half century. ${ }^{13}$ The unipolar yet implosive world of the early twenty-first century seems subject to a systemic malaise to which writers of the left such as Badiou are beginning to respond in Pauline terms. ${ }^{114}$ The category of interest is beginning to seem far less ameliorable than it did to Enlightenment optimists concerned with unlocking the grip of original sin from the idea of human nature. A Hamlet laden with religious doubt could be more historically illuminating than ever, if we better understand Hamlet's entrapment, his anxiety, and his "kind of fighting" (F 5.2.4). If such a reading recalls Luther's spiritual struggle (Anfechtung), it might look forward to Kierkegaard's political theology and Badiou's political reading of St. Paul. ${ }^{115}$

${ }^{112}$ Simon Critchley, Faith of the Faithless: Experiments in Political Theology (London: Verso, 2012).

${ }^{113}$ Koh (see n. 85 above).

114 Alain Badiou, Manifesto for Philosophy, ed. and trans. Norman Madrasz (Albany: SUNY Press, 1999).

115 Anfechtung, Luther's autobiographically and tragically loaded term for spiritual struggle (linking Luther himself with Cain and Orestes [Luther's Works, 1:287]) looks back to the spiritual ordeals of the psalmists and forward to Kierkegaardian anxiety: "This is not a physical thirst ... but a thirst of the soul ... it feels its sin, it is conscious of a weakness of spirit, soul, and flesh; it is aware of a menacing God.... Such anxiety marks the proper thirst. It is natural that people who live in fear, amid temptation [Anfechtung] and distress, are athirst by reason of their anxiety" (Luther's Works, 23:267-68). 